THE Journal OF The Brazilian Crustacean Society

e-ISSN 2358-2936 www.scielo.br/nau www.crustacea.org.br

\title{
Relative growth of Menippe frontalis (Crustacea: Brachyura) in the Gulf of Guayaquil, Ecuador, by multi-model approach
}

\author{
René Zambrano (D) orcid.org/0000-0002-0603-7475 \\ John Ramos (D) orcid.org/0000-0002-9325-7256
}

\begin{abstract}
Departamento de Ciencias del Mar, Carrera de Biología, Facultad de Ciencias Naturales, Universidad de Guayaquil. Av. Raul Gómez Lince S/N y Av. Juan Tanca Marengo, Guayaquil, Guayas 090601, Ecuador. RN E-mail: eddie_zam89@hotmail.com

JRE-mail: lex_ramos92@outlook.es

ZOOBANK: http://zoobank.org/urn:lsid:zoobank.org:pub:6ED24F4B-851C-495180DB-B074ABBA9F75
\end{abstract}

\begin{abstract}
Relative growth can help to identify dimorphism between individuals, and it is also used to determine changes in ontogeny related to sexual maturity. The morphometric variables recorded were width, length and height in carapace and chelae. The abdomen width was taken only in females. Data analysis was made separating males and females. Exploratory analysis used maximum, minimum and mean values and compared these values between sexes using MANOVA, ANOVA and LSD-Fisher methods. A weight-size relationship was also determined. Relative growth was estimated using a multi-model approach. Six models were applied, and the best was selected using Akaike and Bayesian information criteria. Residual versus predicted graphics were also produced based on the selected models. The mean sizes were similar between sexes, but the maximum values were observed in males. The weight-size relationships showed a negative allometry. The best model varied by morphometric variables and sex, but the type of relative growth was principally isometric and negative allometry. Biometric characteristics in Menippe frontalis A. Milne-Edwards, 1879 did not show abrupt changes in the relative growth. The threshold was not assumed as an indicator of morphometric sexual maturity however, they may be used for establishing legal minimum size in M. frontalis.
\end{abstract}

CORRESPONDING AUTHOR René Zambrano eddie_zam89@hotmail.com

SUBMITTED 21 October 2019 ACCEPTED 06 April 2020

PUBLISHED 22 July 2020

DOI $10.1590 / 2358-2936 e 2020030$

\section{(c) BY}

All content of the journal, except where identified, is licensed under a Creative Commons attribution-type BY.

Nauplius, 28: e2020030

\section{KeYWORDS}

Morphometry, multi-model approach, Pangora, relative growth, stone crab 


\section{INTRODUCTION}

The stone crab Menippe frontalis A. Milne-Edwards, 1879 is distributed from México to Peru, and it inhabits the rocks between the edges of protected beaches and the boulders or cliffs that form the promontory adjacent to the beach (Crane, 1947; Hendrickx, 1992; 1995). Menippe frontalis have been reported from the continental coast of Ecuador, and it is considered an analogous species with M. mercenaria (Say, 1818), which inhabits the Atlantic Ocean (Mayer and Giesbrecht, 1883; Faxon, 1895; Garth, 1946).

No formal fisheries of $M$. frontalis exist, and therefore they are captured as fauna associated with lobster fisheries (genus Panulirus White, 1847) in the Gulf of California (Mexico) and Peru (Hendrickx, 1995; Carbajal and Santamaría, 2017). In Ecuador, M. frontalis is known as "pangora" and supports an unregulated commercial fishery.

Ayón-Parente and Hendrickx (2002) noted that the publications about $M$. frontalis are principally systematic studies as well as checklists and field guides (Milne-Edwards, 1879; Mayer and Giesbrecht, 1883; Faxon, 1895; Rathbun, 1930; Garth, 1946; Crane, 1947; Holthuis, 1954; Hendrickx, 1992; 1993; 1995). Three studies exist (as grey literature) on $M$. frontalis in Ecuador. One suggests that it is a species of commercial importance (Correa, 1993), while another characterizes the fishery in Posorja. We found only one work related to relative growth in $M$. frontalis, which is only briefly descriptive due to the low number of specimens analyzed (54 individuals) (Ayón-Parente and Hendrickx, 2002).

Relative growth analyzes the body shape and identifies differences through morphometric relationships (Toro-Ibacache et al., 2010). It is used as a tool in determining changes in body proportions associated with sexual dimorphism, differences between development phases (i.e., juveniles and adults), and differences between sexes or within each sex (Dalabona et al., 2005; Hartnoll, 2012). These latter differences are important for estimating morphometric sexual maturity, which is a relevant population parameter for commercial species, like $M$. frontalis, due to its application in fishery management (Bertini et al., 2007).

Analyses of relative growth apply common logarithmic transformations and linear models, and is based principally on Huxley's work (1932). Geometric morphometrics is another way used in crustaceans (Silva and Paula, 2008; Alencar et al., 2014; Kalate et al., 2018) using specialized software. RodríguezDomínguez et al. (2018) studied the relative growth in Callinectes bellicosus Stimpson, 1859 based on a multimodel approach. They showed that it is incorrect to define a priori the linear or power model as the best for representing the data. Clayton (1990) mentioned that relative growth does not always show developmental phases (i.e., juveniles and adults) that allow estimates of morphometric sexual maturity.

Weight-size relationships are not of great interest to current fisheries science (Hilborn and Walters, 1992; Froese, 2006) however, they are useful for ecological studies like estimating fish weight for underwater visual censuses, or for estimating input data in stock assessment models (Kulbicki et al.,2005; King, 2007). For $M$. frontalis, there is no previous record documenting a weight-size relationship, which is necessary for stock assessments and management, considering that data recorded are usually sizes, and the information necessary for establishing catches and estimation of biomass is weight (Froese, 2006; Froese et al., 2014).

Due to the divergence in the criteria, the aim of this paper is to determine the best model for analyzing relative growth in $M$. frontalis by a multi-model approach, as well as to identify some morphometric relationships useful for estimating sexual maturity.

\section{Material and Methods}

The crabs $(\mathrm{n}=280)$ were collected in May, July and October 2018 from commercial catches in Posorja port, Gulf of Guayaquil, Ecuador. The recorded variables included width, length and height for the carapace $(\mathrm{CW}, \mathrm{CL}, \mathrm{CH})$, right chelae (RCW, $\mathrm{RCL}$, RCH) and left chelae (LCW, LCL, LCH) by sex (Fig. 1). The individual weight (W) was measured for males and females and the abdomen width (AW) was recorded only for females. The measures were recorded by a digital Vernier caliper and a digital balance, with an accuracy level of $0.01 \mathrm{~mm}$ and $0.01 \mathrm{~g}$, respectively (Overton and Macintosh, 2002; Maccormack and DeMont, 2003; Josileen, 2011). The database was uploaded to Mendeley Data (Zambrano and Ramos, 2019). 

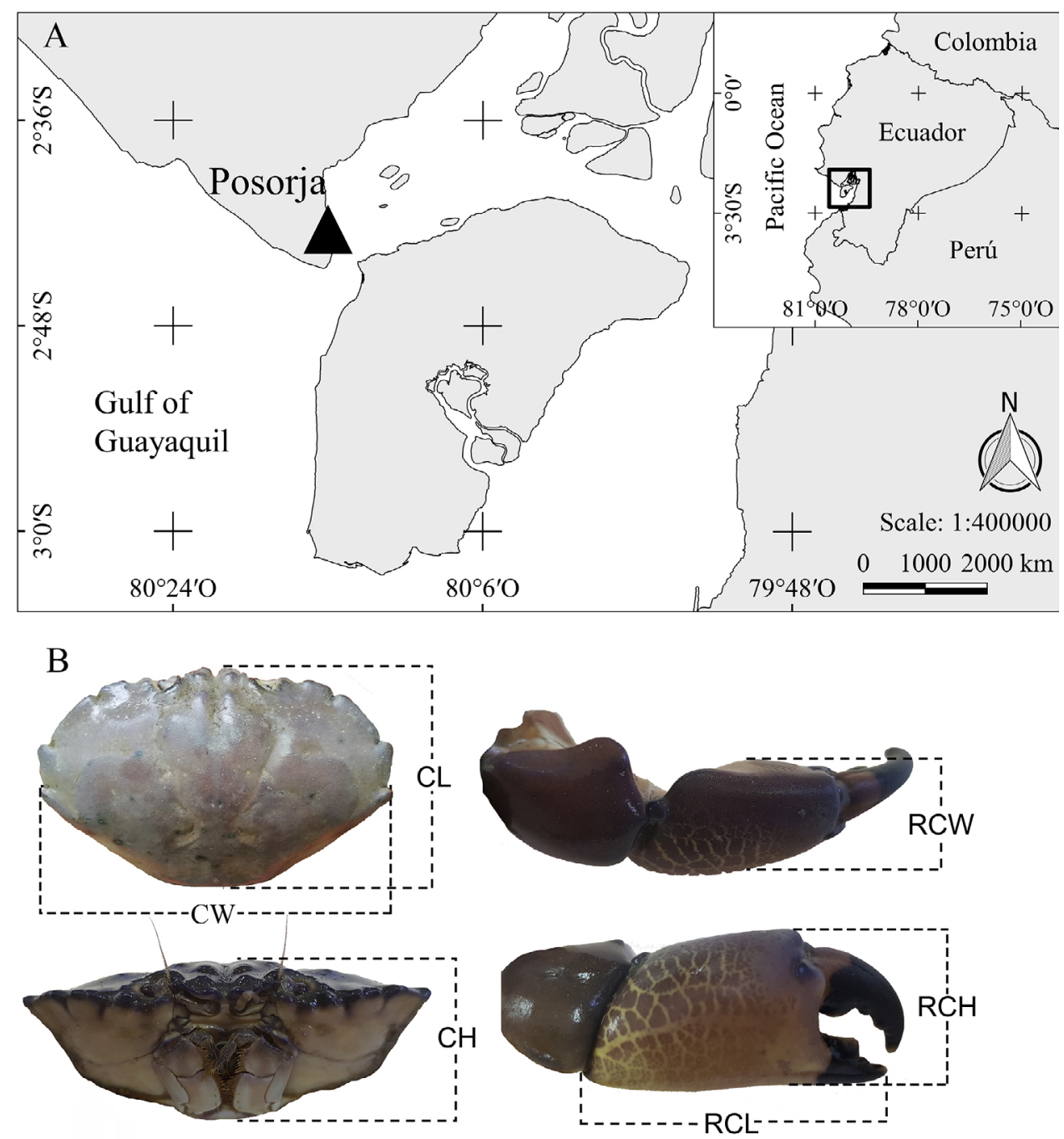

Figure 1. A: Sampling site in Posorja, Gulf of Guayaquil, Ecuador. B: Morphometric variables recorded for Menippe frontalis. CL, carapace length; CW, carapace width; $\mathrm{CH}$, carapace height; RCW, right chela width; $\mathrm{RCH}$, right chela height; RCL, right chela length.

The data analysis was made separating males and females. An exploratory analysis used minimum and maximum sizes, mean $(\bar{x})$ and standard deviation $(S D)$ values. Also, the carapace variables (CW, CL, $\mathrm{CH}$ ) were compared between sexes by a multivariate analysis of variance (MANOVA), including the Hotelling test for multiple comparisons with Bonferroni's correction using InfoStat software (Di Rienzo et al., 2016; Kalate et al., 2018). The differences between carapace variables were established by an analysis of variance (ANOVA) and the least difference test of Fisher, assuming normality in the data by the central limit theorem (Dytham, 2011).

The weight-size relationship was made fitting the power function $\left(y=a+x^{\mathrm{b}}\right)$ to the raw data using the least-squares method (Dalabona et al., 2005; Josileen, 2011). The $\mathrm{W} \times \mathrm{CW}$ and CL relationships were complemented with the data collected by VélezCedeño (2017); those data (in cm) were transformed to millimeters and decimal numbers were added as random numbers with a uniform distribution (Sanvicente-Añorve et al., 2003). That process was completed in Stata 15.1 software using the following code sequence: gen dec $=$ uniform ()$\rightarrow$ gen decimals $=$ dec- $0.5 \rightarrow$ gen var $2=$ var $1+$ decimals; varl is the variable entered (i.e., size, weight), and var 2 is the same variable with decimals.

The pattern of allometry for weight-size relationships was established as follows: negative, $b<3$; positive, $b>3$; isometry, $b=3$ (Widigdo et al., 2017). The relative growth was analyzed by log-transforming all measurements. The carapace dimensions were used as the independent variable, and the chelae were the dependent variables (Silva et al., 2014). 
The $\mathrm{CL} \times \mathrm{CW}$ and $\mathrm{CH} \times \mathrm{CW}$ relationships, as well as $\mathrm{AW} \times \mathrm{CW}, \mathrm{CL}$, and $\mathrm{CH}$, were analyzed too. Six candidate models were fitted to the transformed data (Hall et al., 2006; Prototapas et al., 2007; Rodríguez-Domínguez et al., 2018) for selecting the best model (Chart 1):

Chart 1. Equations and abbreviations from candidate models used

\begin{tabular}{|lcl|}
\hline Models & Abb. & \multicolumn{1}{c|}{ Equations } \\
\hline Linear & LM & $\operatorname{Ln}(y)=\operatorname{Ln}\left(a_{1}\right)+b_{1} \operatorname{Ln}(x)$ \\
Quadratic & QM & $\operatorname{Ln}(y)=\operatorname{Ln}\left(a_{1}\right)+b_{1} \operatorname{Ln}(x)+b_{2} \operatorname{Ln}(x)^{2}$ \\
Cubic & CM & $\operatorname{Ln}(y)=\operatorname{Ln}\left(a_{1}\right)+b_{1} \operatorname{Ln}(x)+b_{2} \operatorname{Ln}(x)^{2}+b_{3} \operatorname{Ln}(x)^{3}$ \\
& & $\operatorname{Ln}(y)=\operatorname{Ln}\left(a_{1}\right)+b_{1} \operatorname{Ln}(x)$ if $x \leq B_{1}$ \\
Broken stick & BSM & $\left.\operatorname{Ln}(y)=\operatorname{Ln}\left(a_{1}\right)+b_{1}-b_{2}\right) \operatorname{Ln}\left(B_{1}\right)^{2}+b_{2} \operatorname{Ln}(x)$ if $x>B_{1}$ \\
Two & & $\operatorname{Ln}(y)=\operatorname{Ln}\left(a_{1}\right)+b_{1} \operatorname{Ln}(x)$ if $x \leq B_{1}$ \\
segments & TwSM & $\operatorname{Ln}(y)=\operatorname{Ln}\left(a_{2}\right)+b_{2} \operatorname{Ln}(x)$ if $x>B_{1}$ \\
Three & & $\operatorname{Ln}(y)=\operatorname{Ln}\left(a_{1}\right)+b_{1} \operatorname{Ln}(x)$ if $x \leq B_{1}$ \\
segments & ThSM & $\operatorname{Ln}(y)=\operatorname{Ln}\left(a_{2}\right)+b_{2} \operatorname{Ln}(x)$ if $B_{1}<x<B_{2}$ \\
& & $\operatorname{Ln}(y)=\operatorname{Ln}\left(a_{2}\right)+b_{3} \operatorname{Ln}(x)$ if $x>B_{2}$
\end{tabular}

Where, $a=$ intercept; $b=$ slope; $x=$ independent morphometric variable; $y=$ depending morphometric variable; and $B_{1}=$ threshold.

The initial values for $a$ (intercept), $b$ (slope) and $B_{1}$ (threshold) were established $a$ priori. The parameters were optimized using the maximum log-likelihood $L L=-\frac{n}{2}[\operatorname{Ln}(2 \pi)+2 \operatorname{Ln}(\hat{\sigma}+1]$, where $\hat{\sigma}=\sqrt{\sum_{i=1}^{n} \frac{\left(\operatorname{Ln}\left(x_{i}\right)-\operatorname{Ln}\left(\hat{x}_{i}\right)\right)^{2}}{n}}$ (Haddon, 2011). $B_{2}$ and $B_{3}$ were estimated by a threshold regression model included in Stata 15.1 software.

The code used was threshold $y x$, nthresholds(2) threshvar $(x)$ where $y$ and $x$ are the names of the dependent (e.g., chelae) and independent (i.e., carapace) morphometric variables, respectively. Graphics of residual versus predicted values were generated for analyzing the data distribution in relation to all the models (Salgado-Ugarte, 2013).

The best model was selected using "the weight of evidence" in favor of model $i\left(W_{\mathrm{i}}\right)$, estimated for the Akaike and Bayesian information criteria (AIC and $B I C)$ (Akaike, 1973; Schwarz, 1978). For AIC, the bias corrected version $\left(A I C_{c}\right)$ was used due to $n / K<$
40 for the model with the largest value of $K$ (Hurvich and Tsai, 1989; Burnham and Anderson, 2004). The procedure is discussed in detail in Burnham and Anderson $(2002 ; 2004)$.

The best models were selected using three criteria: i) the best model showed the highest $W_{\mathrm{i}} A I C_{\mathrm{c}}-B I C$ values; $i$ ) the best model presented $W_{\mathrm{i}}$ value $>0.6$ and the highest $W_{\mathrm{i}}$ values were different between criteria, but these models did not include the two-segment model; iii) the best model showed the highest $W_{\mathrm{i}}$ value. In this case, one of the models that was selected was a two-segment model, and therefore the Draper and Smith (1966) test was used.

The Draper and Smith (1966) test performed validation by statistically fitting two lines to the data (Somerton, 1980) if $F_{\mathrm{tab}}<F_{\mathrm{cal}}$. That procedure was used in scenario $i$ as well, when the best model consisted of two segments, and it was compared with a linear model (Corgos and Freire, 2006; Koga et al., 2010). The allometry level for the morphometric relationships was established using the following slope values: negative, $b<1$; positive, $b>1$; isometry, $b=1$ (Huxley, 1932; Hartnoll, 1974; 1983; 2012; McLay, 2015).

\section{ResULtS}

The total sample consisted of 155 females and 125 males. The minimum and average values of CW, CL and $\mathrm{CH}$ were similar between sexes, while, maximum values where higher in males (Tab. 1). The $\mathrm{CH}$ was different by sex $(\mathrm{p}<0.05)$, but the CW and CL did not show significant differences between males and females (Tab. 1).

The weight-size relationship showed slope values (b) that were higher in males, with differences of $15 \%, 16 \%$ and $33 \%$ for $\mathrm{CW}, \mathrm{CL}$ and $\mathrm{CH}$, respectively (Fig. 2). All cases presented negative allometric growth $(b<3)$. The residual $\times$ predicted showed unbiased and heteroscedastic data (Fig. 2). The morphometric relationship presented differences on the best model selected (Figs. 3, 4).

Table 1. Minimum, maximum, mean and standard deviation (SD) size values recorded by sex in Menippe frontalis in the Gulf of Guayaquil. Probability values (p) from the ANOVA to test for differences in size between sexes, and least significative differences of Fisher (LSD).

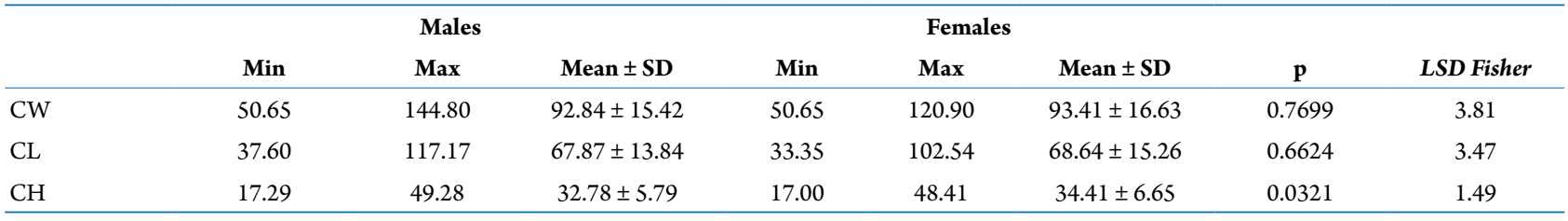




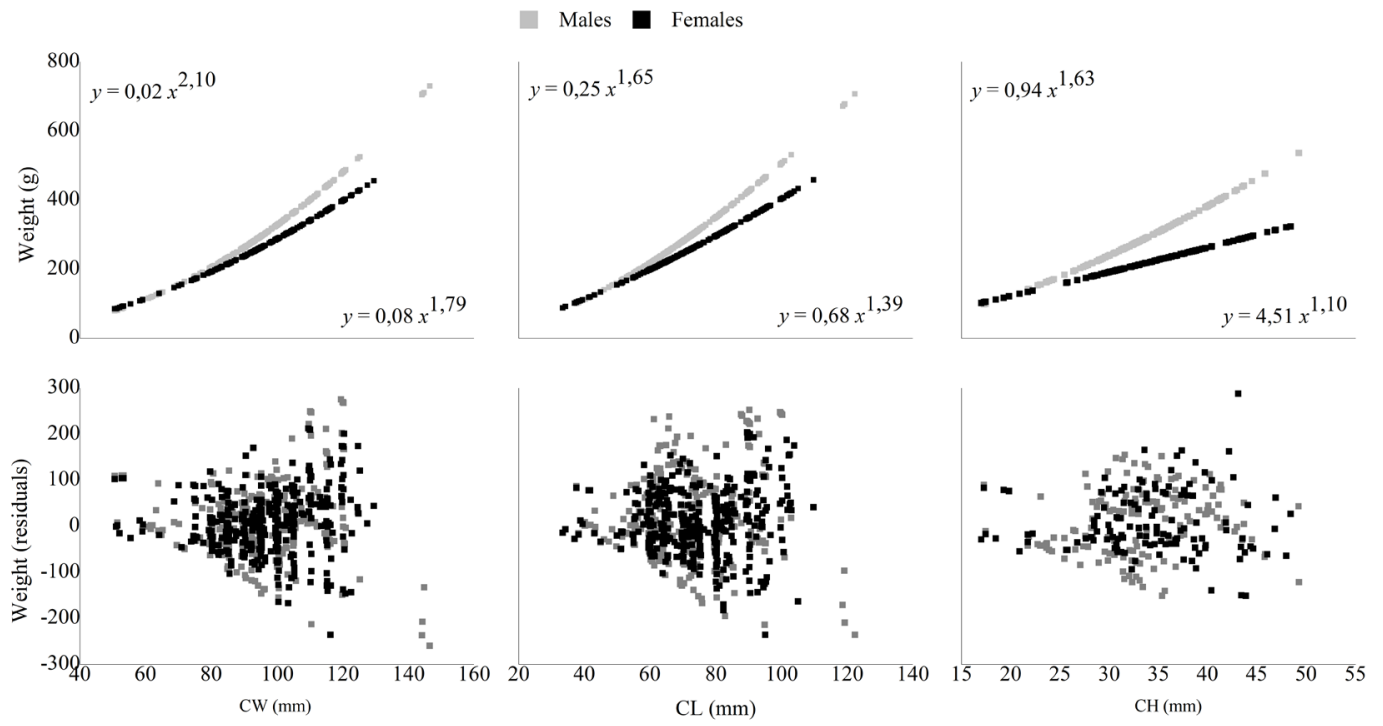

Figure 2. Weight-Size relationships of Menippe frontalis in Posorja, Gulf of Guayaquil, Ecuador, and residuals vs predicted values obtained from the power model. CW, carapace width; CL, Carapace length; CH, carapace height.
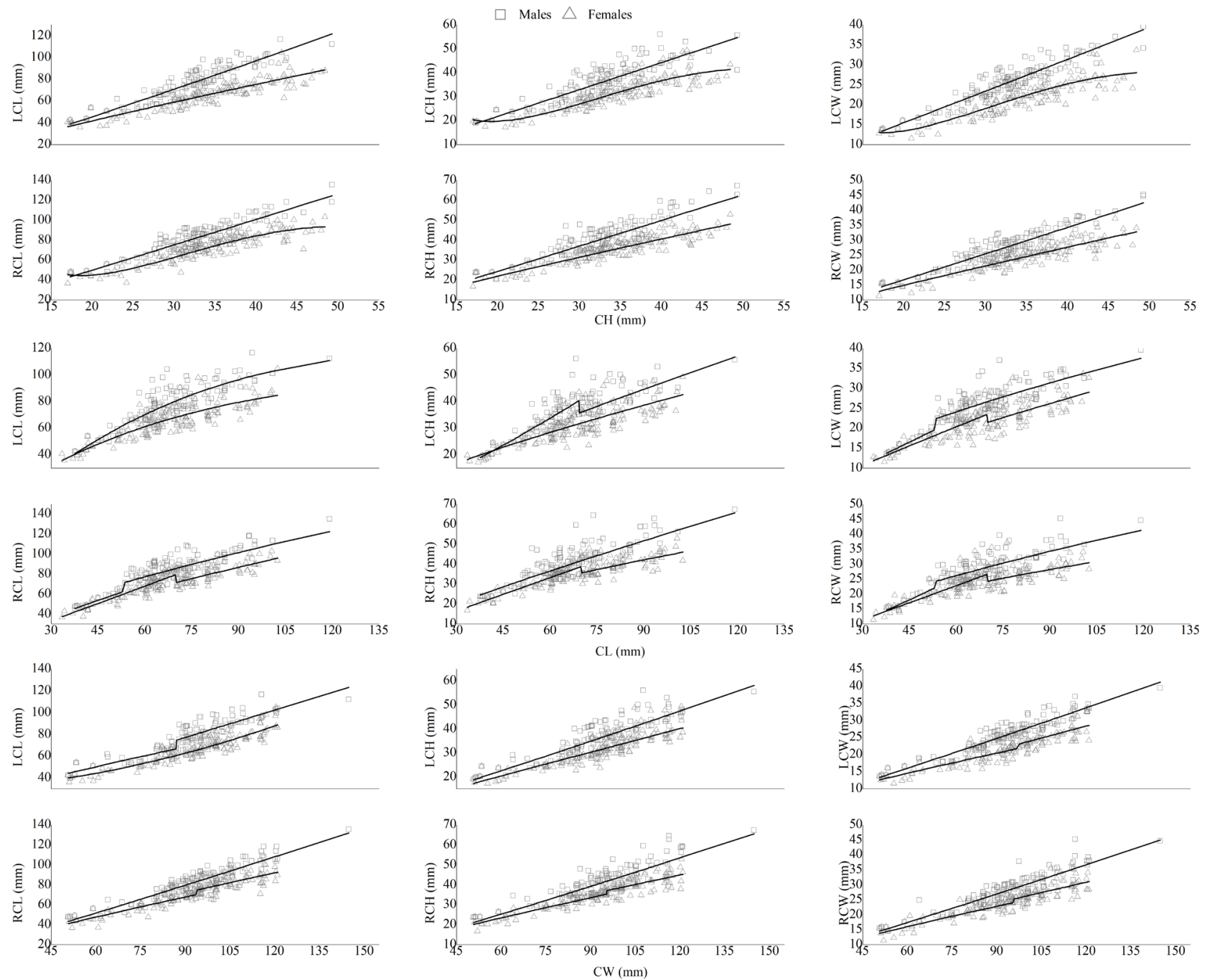

Figure 3. Raw data and the best models fitted to each morphometric relationship established for Menippe frontalis in the Gulf of Guayaquil, Ecuador. CW, carapace width; $\mathrm{CL}$, carapace length; $\mathrm{CH}$, carapace height; LCL, left chelae length; LCH, left chelae height; LCW, left chelae width; RCL, right chelae length; $\mathrm{RCH}$, right chelae height; RCW, right chelae width. 
The linear model was the best principally for chelae dimensions $\times \mathrm{CW}$ and $\mathrm{CH}$ in males. For chelae variables $\times C L$, the two-segments model was the best in both sexes. For females, the best models were the quadratic model for chelae $\times \mathrm{CW}$ and the cubic model for chelae $\times \mathrm{CH}$ (Tab. 2).

In the carapace relationships and abdomen, the best models were linear for $\mathrm{CH} \times \mathrm{CW}$ (both sexes) and $\mathrm{CL} \times \mathrm{CW}$ (females), quadratic for $\mathrm{CL} \times \mathrm{CW}$ (males) and $\mathrm{AW} \times \mathrm{CW}$ (females), cubic for $\mathrm{AW} \times \mathrm{CH}$ (females), two-segments for $\mathrm{CH} \times \mathrm{CL}$ (both sexes) and $\mathrm{AW} \times \mathrm{CL}$ (females). The types of relative growth based on the best models were principally isometric and negative allometric (Tab. 2). The threshold values were between 50 to $70 \mathrm{~mm} \mathrm{CL}$ and 85 to $95 \mathrm{~mm} \mathrm{CW}$ (Figs. 3, 4). The residual $\times$ predicted values showed unbiased and heteroscedastic data (Figs. 5, 6).
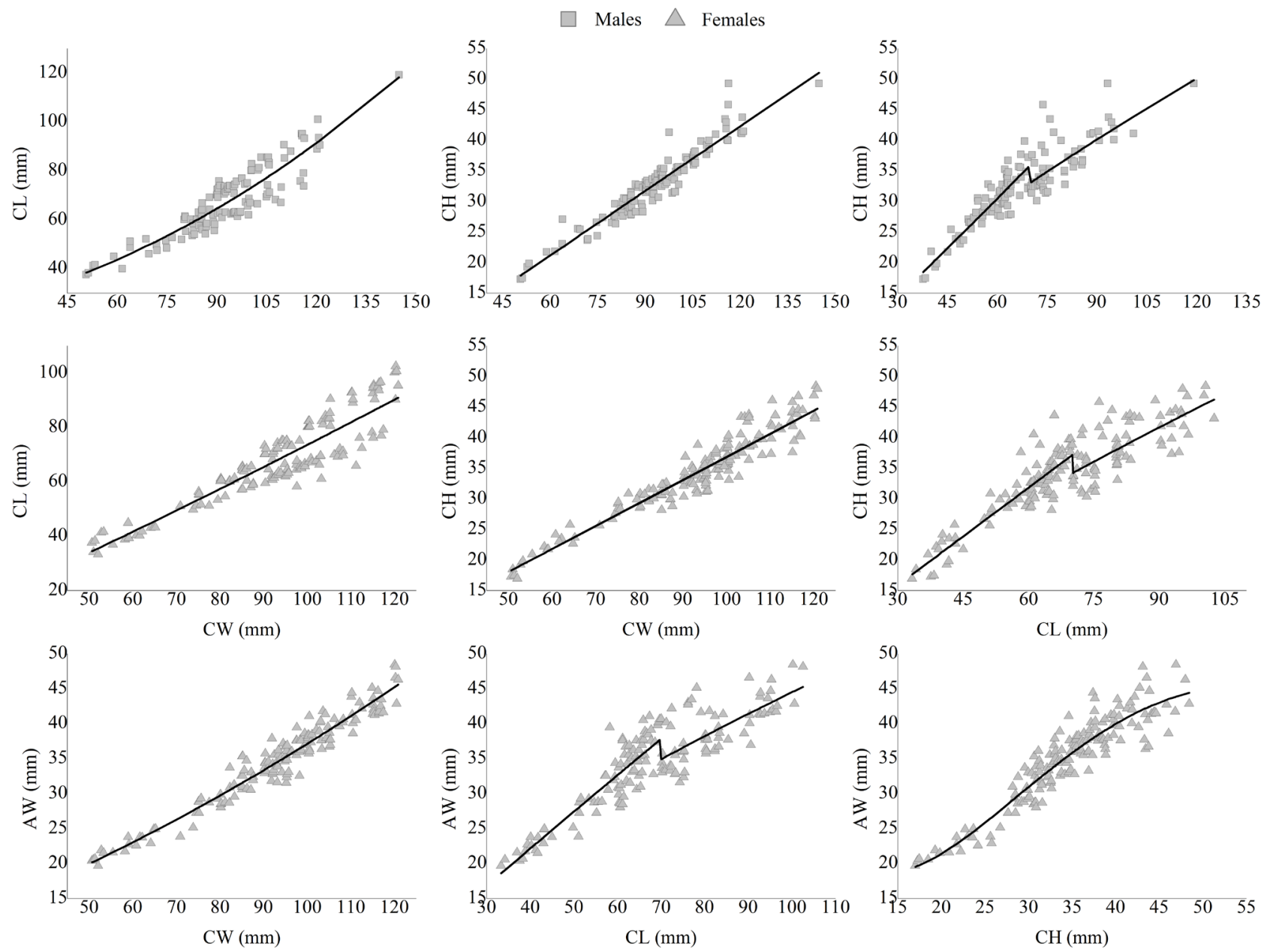

Figure 4. Raw data and the best models fitted to the morphometric relationships of Menippe frontalis in the Gulf of Guayaquil, Ecuador. CW, carapace width; CL, Carapace length; $\mathrm{CH}$, carapace height; AW, abdomen width. 
Table 2. Parameters of the best models (BM) selected based on the criteria $i\left({ }^{*}\right), i i\left(^{* *}\right)$ and $i i\left(^{* * *}\right)$ for the morphometric relationships of Menippe frontalis in the Gulf of Guayaquil, Ecuador. LCL, left chelae length; LCH, left chelae height; LCW, left chelae width; RCL, right chelae length; $\mathrm{RCH}$, right chelae height; $\mathrm{RCW}$, right chelae width; $\mathrm{CW}$, carapace width; $\mathrm{CL}$, Carapace length; $\mathrm{CH}$, carapace height; AW, abdomen width. LM, linear model; QM, quadratic model; CM, cubic model; TwSM, two segment model.

\begin{tabular}{|c|c|c|c|c|c|c|c|c|c|c|c|c|c|}
\hline \multirow{3}{*}{ Carapace } & \multicolumn{6}{|c|}{ Males } & \multicolumn{7}{|c|}{ Females } \\
\hline & & & & & & & & & & & & & \\
\hline & $\mathrm{BM}$ & $a_{1}$ & $b_{1}$ & $a_{2}$ & $b_{2}$ & $B_{1}$ & $\mathrm{BM}$ & $a_{1}$ & $b_{1}$ & $a_{2}$ & $b_{2}$ & $b_{3}$ & $B_{1}$ \\
\hline LCL & $\operatorname{TwSM}(*)$ & 0.79 & 0.76 & -0.04 & 0.98 & 4.47 & $\mathrm{QM}\left({ }^{*}\right)$ & 2.04 & 0.35 & & 0.07 & & \\
\hline $\mathrm{LCH}$ & $\operatorname{LM}(* * *)$ & -1.28 & 1.07 & & & & $\mathrm{QM}(*)$ & 9.58 & -3.85 & & 0.55 & & \\
\hline LCW & $\operatorname{LM}(* * *)$ & -1.62 & 1.07 & & & & $\mathrm{QM}(*)$ & 7.25 & -2.93 & & 0.44 & & \\
\hline RCL & $\mathrm{LM}\left({ }^{*}\right)$ & -0.39 & 1.06 & & & & $\mathrm{CM}\left({ }^{*}\right)$ & 59.64 & -50.80 & & 15.15 & -1.47 & \\
\hline $\mathrm{RCH}$ & $\operatorname{LM}\left({ }^{* *}\right)$ & 0.09 & 1.03 & & & & $\mathrm{CM}\left({ }^{* *}\right)$ & 45.35 & -39.34 & & 11.95 & -1.18 & \\
\hline $\mathrm{RCW}$ & $\mathrm{LM}\left({ }^{*}\right)$ & -1.54 & 1.07 & & & & $\operatorname{LM}(* * *)$ & -1.17 & 0.96 & & & & \\
\hline $\mathrm{CL}$ & $\mathrm{QM}\left({ }^{*}\right)$ & 6.31 & -2.06 & & 0.35 & & $\operatorname{LM}\left({ }^{* *}\right)$ & -0.83 & 1.11 & & & & \\
\hline $\mathrm{CH}$ & $\operatorname{LM}\left(^{*}\right)$ & -1.04 & 1.00 & & & & $\operatorname{LM}\left({ }^{* * *}\right)$ & -1.12 & 1.03 & & & & \\
\hline AW & & & & & & & $\mathrm{QM}\left({ }^{*}\right)$ & 3.34 & -0.92 & & 0.21 & & \\
\hline \multicolumn{14}{|c|}{ Carapace length $v s$} \\
\hline $\mathrm{LCL}$ & $\mathrm{QM}\left({ }^{* * *}\right)$ & -6.82 & 4.45 & & -0.43 & & $\mathrm{QM}\left({ }^{* * *}\right)$ & -3.63 & 3.03 & & -0.28 & & \\
\hline $\mathrm{LCH}$ & $\operatorname{TwSM}\left({ }^{*}\right)$ & -1.54 & 1.24 & -0.03 & 0.85 & 4.24 & $\operatorname{LM}\left({ }^{* *}\right)$ & 0.26 & 0.75 & & & & \\
\hline LCW & $\operatorname{TwSM}\left({ }^{*}\right)$ & -1.11 & 1.03 & 0.54 & 0.65 & 3.97 & $\operatorname{TwSM}\left({ }^{* * *}\right)$ & -0.78 & 0.93 & -0.28 & 0.79 & & 4.25 \\
\hline $\mathrm{RCL}$ & $\operatorname{TwSM}\left({ }^{*}\right)$ & 0.49 & 0.92 & 1.59 & 0.67 & 3.97 & TwSM $\left(^{*}\right)$ & 0.03 & 1.02 & 1.01 & 0.77 & & 4.25 \\
\hline $\mathrm{RCH}$ & $\operatorname{LM}(* * *)$ & 0.11 & 0.85 & & & & TwSM $\left(^{*}\right)$ & -0.59 & 1.00 & 0.73 & 0.67 & & 4.25 \\
\hline RCW & $\operatorname{TwSM}\left({ }^{*}\right)$ & -1.67 & 1.2 & 0.55 & 0.66 & 3.97 & $\operatorname{TwSM}\left({ }^{*}\right)$ & -0.96 & 1.00 & 0.66 & 0.6 & & 4.25 \\
\hline $\mathrm{CH}$ & $\operatorname{TwSM}(*)$ & -0.99 & 1.08 & 0.23 & 0.77 & 4.24 & $\operatorname{TwSM}\left({ }^{*}\right)$ & -0.64 & 1.00 & 0.16 & 0.79 & & 4.25 \\
\hline AW & & & & & & & $\operatorname{TwSM}\left({ }^{*}\right)$ & -0.43 & 0.96 & 0.67 & 0.68 & & 4.25 \\
\hline \multicolumn{14}{|c|}{ Carapace height $v s$} \\
\hline LCL & $\operatorname{LM}(* * *)$ & 0.56 & 1.09 & & & & $\operatorname{LM}\left({ }^{* *}\right)$ & 1.19 & 0.85 & & & & \\
\hline $\mathrm{LCH}$ & $\operatorname{LM}\left({ }^{* *}\right)$ & 0.02 & 1.02 & & & & $\mathrm{CM}\left({ }^{*}\right)$ & 62.49 & -53.62 & & 15.85 & -1.53 & \\
\hline LCW & $\operatorname{LM}(* * *)$ & -0.3 & 1.02 & & & & $\mathrm{CM}\left({ }^{*}\right)$ & 45.65 & -39.73 & & 11.97 & -1.17 & \\
\hline $\mathrm{RCL}$ & $\operatorname{LM}\left({ }^{* * *}\right)$ & 0.88 & 1.01 & & & & $\mathrm{CM}\left({ }^{*}\right)$ & 28.33 & -23.1 & & 7.07 & -0.69 & \\
\hline $\mathrm{RCH}$ & $\operatorname{LM}\left({ }^{*}\right)$ & 0.09 & 1.03 & & & & $\operatorname{LM}(* * *)$ & 0.44 & 0.89 & & & & \\
\hline RCW & $\operatorname{LM}(* * *)$ & -0.27 & 1.03 & & & & $\operatorname{LM}(* *)$ & 0.04 & 0.89 & & & & \\
\hline AW & & & & & & & $\mathrm{CM}\left({ }^{*}\right)$ & 28.83 & -24.78 & & 7.70 & -0.77 & \\
\hline
\end{tabular}



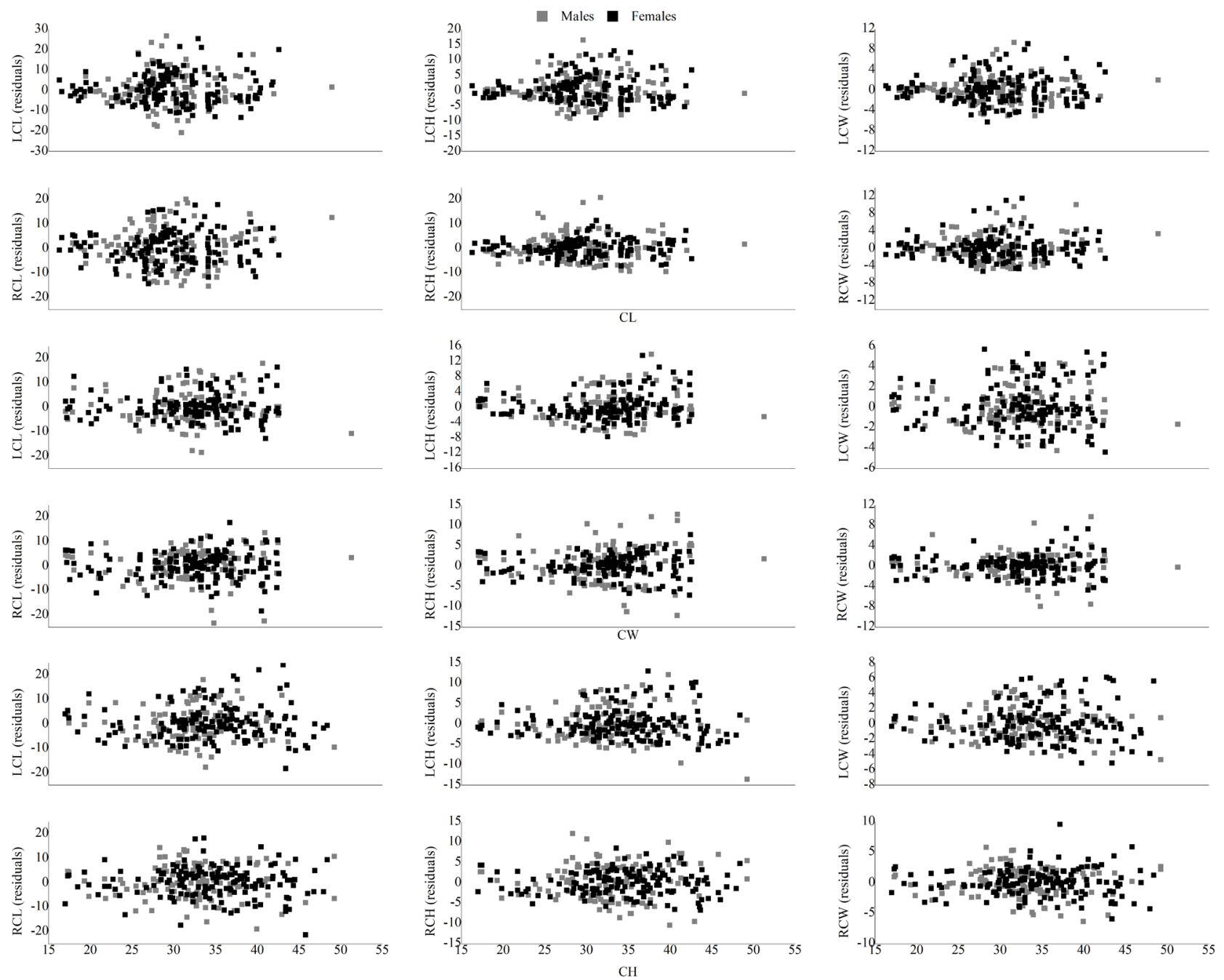

Figure 5. Residual values from the best models fitted to the morphometric data of Menippe frontalis in the Gulf of Guayaquil, Ecuador. CW, carapace width; CL, Carapace length; CH, carapace height; LCL, left chelae length; LCH, left chelae height; LCW, left chelae width; RCL, right chelae length; RCH, right chelae height; RCW, right chelae width.
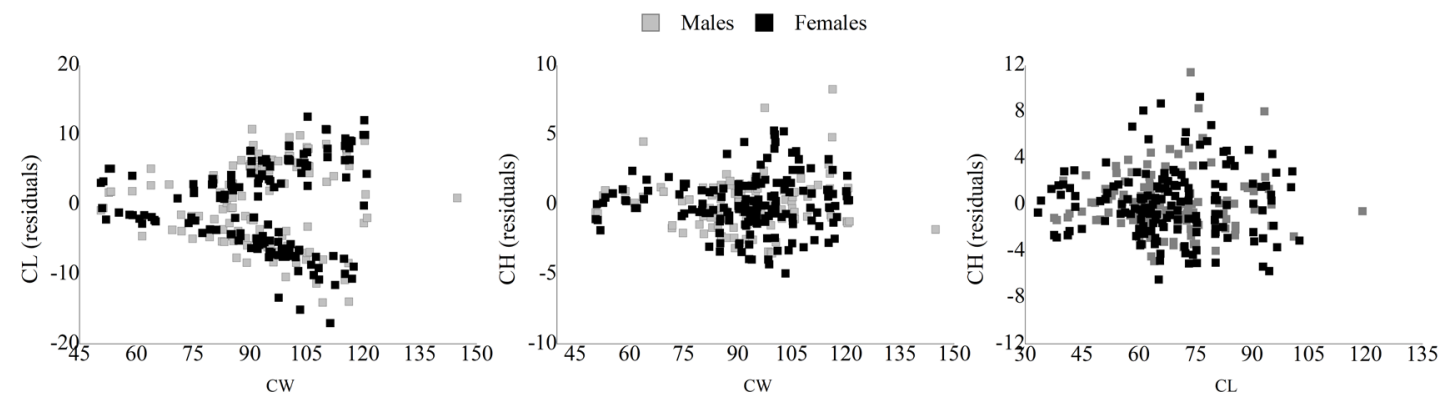

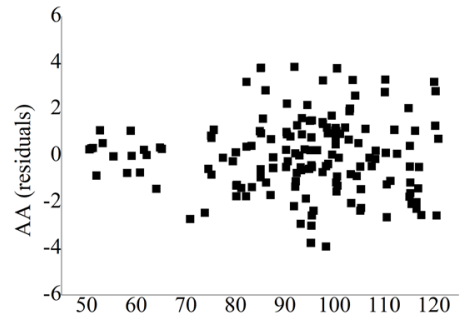

$\mathrm{CW}$

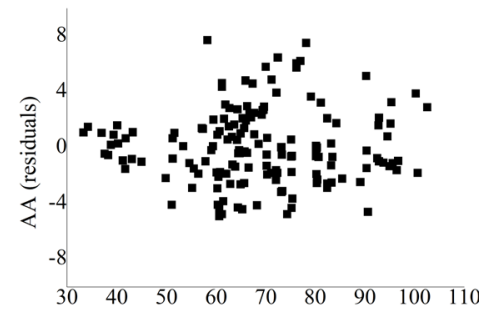

CL

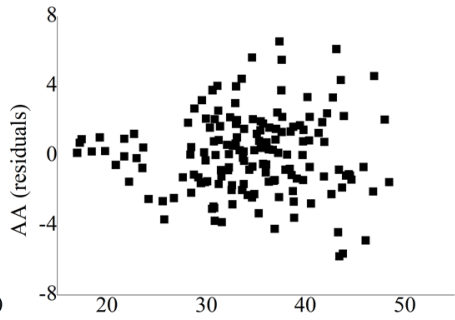

$\mathrm{CH}$

Figure 6. Residual values from the best models fitted to the morphometric data of Menippe frontalis in the Gulf of Guayaquil, Ecuador. $\mathrm{CW}$, carapace width; $\mathrm{CL}$, Carapace length; $\mathrm{CH}$, carapace height; $\mathrm{AW}$, abdomen width. 


\section{DIsCUSSION}

The relative growth differed according to morphometric relationship and sex in M. frontalis, and consequently the parameter and allometry must be specifically analyzed. In addition, we did not find an abrupt change in the relative growth which could be related to morphometric sexual maturity. Our results show that the linear model is not always the best option for estimating the relative growth. Similarly, for Pachygrapsus marmoratus (Fabricius, 1787) and Callinectes bellicosus Stimpson, 1859 the best models included cubic, broken stick, and twosegments model depending on the morphometric variable used (Prototapas et al., 2007; RodríguezDomínguez et al., 2018).

In relative growth studies of crustaceans, the most common is to use a linear model with $\log$ transformation (Huxley, 1932; Hartnoll, 2012; Kalate et al., 2018). Based on this, many works have been developed in different species, such as Leptuca thayeri Rathbun, 1900, Aratus pisonii (H. Milne Edwards, 1837), Armases rubripes (Rathbun, 1897), Halicarcinus cookii (Filhol, 1885), Portunus sanguinolentus (Herbst, 1783), P. pelagicus (Linnaeus, 1758), and Eriocheir japonica (De Haan, 1835) (McLay and Van den Brink, 2009; Sukumaran and Neelakantan, 2010; Araújo et al., 2012; Zhang et al., 2017; Marochi et al.,2018). For relative growth studies it is best to not use the linear model a priori, but instead to test several models, selecting the most appropriate one according to the biology of the species.

Our morphometric relationship presented isometry and negative allometry for the best models, while Ayón-Parente and Hendrickx (2002) found positive allometry between $\mathrm{CL} \times \mathrm{CW}$ in Menippe frontalis. This difference probably can be related to sample size, since Ayón-Parente and Hendrickx (2002) only collected 54 specimens and in this study, there were 280 individuals. The negative allometry found in $M$. frontalis means that the weight increases slower than the size. This type of allometry has been observed for crab species such as Scylla serrata (Forskål, 1775), Pachygrapsus marmoratus (Fabricius, 1787), Carcinus aestuarii Nardo, 1847, Liocarcinus depurator (Linnaeus, 1758), L. navigator (Herbst, 1794) and
Eriphia verrucosa (Forskål, 1775) (Widigdo et al., 2017; Aydın, 2018).

We recorded CW sizes greater than those reported by other authors for males and females (e.g., 115.9$128 \mathrm{~mm} \mathrm{CW}$ and $98.4-100 \mathrm{~mm} \mathrm{CW}$, respectively) (Hendrickx, 1995; Ayón-Parente and Hendrickx, 2002). Menippe frontalis also shows sizes generally larger than M. mercenaria, which has maximum sizes reported as $89.5 \mathrm{~mm} \mathrm{CW}$ in Mexico, and 127.4 $\mathrm{mm} \mathrm{CW}$ in males and $114.6 \mathrm{~mm} \mathrm{CW}$ in females for the Florida coast, USA (Cervantes-Martínez and Ramírez-González, 2001; Crowley et al., 2018).

The observed differences in the relative growth and sizes of $M$. frontalis and $M$. mercenaria could be related to geographical distribution and environmental variables, which may be explained by variations in the genetic structure of populations, phenotypic plasticity related to environmental heterogeneity, or a combination of both (Maszczyk and Brzeziński, 2018). Additionally, the difference in maximum sizes between the sexes could be due to female crustaceans commonly preferring dominant males, which are often larger (Subramoniam, 2017).

The weight-size relationship showed that the males of $M$. frontalis were bigger and heavier than the females. This has also been evidenced in other crabs such as Ucides cordatus (Linnaeus, 1763) (Pinheiro and Fiscarelli, 2009). In this sense, it is necessary to separate the data by sex for stock assessment when the models are using the allometry value of weight. Our results suggest that changes in the relative growth of $M$. frontalis are explained by different models, including but not limiting to, the linear model.

The threshold values $\left(B_{1}\right)$ could be assumed to be indicators of morphometric sexual maturity in $M$. frontalis. We assume $70 \mathrm{~mm} \mathrm{CW}$ as the size at onset of morphometric sexual maturity due to it being the most repetitive threshold value in the best models in both sexes. For M. mercenaria, M. adina Williams and Felder, 1986 and their hybrids, the morphometric sexual maturity reported was $71 \mathrm{~mm} \mathrm{CW} \mathrm{in} \mathrm{males} \mathrm{and}$ $59.6 \mathrm{~mm}$ CW in females (Gerhart and Bert, 2008). On the other hand, for M. mercenaria sexual maturity at $63.1 \mathrm{~mm} \mathrm{CW}$ in males and $66.3 \mathrm{~mm} \mathrm{CW}$ in females have been recorded (Crowley et al., 2018). 
Differences in sexual maturity between congeners could be because $M$. frontalis reaches greater sizes, as was mentioned previously. All other species used $\mathrm{CW}$ as an independent variable, but in $M$. frontalis the produced threshold values are so high that we do not consider them as references of sexual maturity. Additionally, this species does not show an abrupt change in their relative growth. Therefore, the results and comparisons should be treated with some caution considering that the data, the analysis and the statistic interpretations could be misleading as biological interpretations (Clayton, 1990).

The linear model was the only one where a morphometric variable useful for determining sexual maturity in $M$. frontalis was not found. A similar case has been observed for males of Homarus americanus $\mathrm{H}$. Milne Edwards, 1837, where sexual morphometric maturity was not detected in their chela (Conan et al., 2001). It is therefore necessary to include more than one model for estimating relative growth in crustaceans, as well as the chelae and other morphometric variables (e.g., carapace dimensions) for estimating sexual maturity. Based on previous guidelines (FAO, 1995), we propose to use our threshold values as the minimum legal size for commercially harvesting M. frontalis.

\section{ACKNOWLEDGEMENTS}

This paper is derived from the bachelor's thesis of John Ramos. The authors thank Javier Tomalá for allowing us to record data from his commercial catches. Additionally, the authors would like to thank Sidney Mendieta, Jorge Peñaherrera and Jorge Poveda for helping to collect the data, as well as Brando Yanez for helping to generate the tables and graphics.

\section{RefERENCES}

Akaike, H. 1973. Information theory and an extension of the maximum likelihood principle.p. 268-281. In: B.N. Petrov and F. Csaki (eds), 2nd International Symposium on Information Theory. Budapest, Akademiai Kiado.

Alencar, C.E.R.D.; Lima-Filho, P.A.; Molina, W.F. and Freire, F.A.M. 2014. Sexual shape dimorphism of the mangrove crab Ucides cordatus (Linnaeus, 1763) (Decapoda, Ucididae) accessed through geometric morphometric. The Scientific World Journal, ID 206168: 1-8.
Araújo, M.S.L.C.; Coelho, P.A. and Castiglioni, D.S. 2012. Relative growth and determination of morphological sexual maturity of the fiddler crab Uca thayeri Rathbun (Crustacea, Ocypodidae) in two mangrove areas from Brazilian tropical coast. PanAmerican Journal of Aquatic Sciences, 7: 156-170.

Aydın, M. 2018. Length-weight relationships and condition factors of five crab species (Decapoda) in the Black Sea, Pakistan. Journal of Zoology, 50: 1519-1524.

Ayón-Parente, M. and Hendrickx, M.E. 2002. Aspects of the biology of the stone crab, Menippe frontalis (Crustacea: Xanthidae), from Southern Sinaloa, Mexico. Contributions to the Study of East Pacific Crustaceans, 1: 89-96.

Bertini, G.; Braga, A.; Fransozo, A.; Corrêa, M. and Freire, F. 2007. Relative growth and sexual maturity of the stone crab Menippe nodifrons Stimpson, 1859 (Brachyura, Xanthoidea) in Southeastern Brazil. Brazilian Archives of Biology and Technology, 50: 259-267.

Burnham, K.P. and Anderson, D.R. 2002. Model selection and multimodel inference: a practical information-theoric approach $\left(2^{\text {nd }}\right.$ ed. $)$. Berlin \& Heidelberg, Springer-Verlag, 488p.

Burnham, K.P. and Anderson, D.R. 2004. Multimodel inference: understanding AIC and BIC in model selection. Sociological Methods and Research, 33: 261-304.

Carbajal, P. and Santamaría, J. 2017. Guía ilustrada para reconocimiento de especies de cangrejos braquiuros y anomuros con valor comercial en Perú. Lima, Instituto del Mar de Perú (Imarpe), 19p.

Cervantes-Martínez, A. and Ramírez-González, A. 2001. Abundancia y tallas de Menippe mercenaria (Crustacea: Brachyura), en refugios artificiales en Quintana Roo, México. Revista de Biologia Tropical, 49: 883-888.

Clayton, D.A. 1990. Crustacean allometric growth: A case for caution. Crustaceana, 58: 270-290.

Conan, G.Y.; Comeau, M. and Moriyasu, M. 2001. Are morphometrical approaches appropriate to establish size maturity for male american lobster, Homarus americanus? Journal of Crustacean Biology, 21: 937-947.

Corgos, A. and Freire, J. 2006. Morphometric and gonad maturity in the spider crab Maja brachydactyla: A comparison of methods for estimating size at maturity in species with determinate growth. ICES Journal of Marine Science, 63: 851-859.

Correa, J. 1993. Crustáceos de mayor importancia comercial en Ecuador. p. 71-88. In: S. Massay; J. Correa and E. Mora (eds), Peces, crustáceos y moluscos de mayor importancia comercial en Ecuador. Guayaquil, Ecuador: Instituto Nacional de Pesca.

Crane, J. 1947. Eastern Pacific Expeditions of the New York Zoological Society. XXXVIII. Intertidal brachygnathous crabs from the West Coast of Tropical America with special reference to ecology. Zoologica: Scientific Contributions of The New York Zoological Society, 32: 69-95.

Crowley, C.E.; Gandy, R.L.; Daly, K.L. and Leone, E.H. 2018. Assessment of maturity in the Eastern Gulf of Mexico Florida stone crab Menippe mercenaria fishery. Transactions of the American Fisheries Society, 147: 1124-1145.

Dalabona, G.; Silva, J.L. and Pinheiro, M.A.A. 2005. Size at morphological maturity of Ucides cordatus (Linnaeus, 1763) (Brachyura, Ocypodidae) in the Laranjeiras Bay, Southern 
Brazil. Brazilian Archives of Biology and Technology, 48: 139-145.

Di Rienzo, J.A.; Casanoves, F.; Balzarini, M.G.; Gonzalez, L.; Tablada, M. and Robledo, C. 2016. InfoStat. Retrieved from http://www.infostat.com.ar

Draper, N.R. and Smith, H. 1966. Applied regression analysis. New York, John Wiley and Sons, Inc., 407p.

Dytham, C. 2011. Choosing and using statistics. A biologist's guide ( $3^{\text {rd }}$ ed.). Wiley-Blackwell, 298p.

FAO. 1995. Código de conducta para la pesca responsable. Roma: FAO, 46p.

Faxon, W. 1895. The Stalk-eyed Crustacea. Reports on an exploration off the west coasts of Mexico, Central and South America, and off the Galapagos islands. In Memoirs of the Museum of Comparative Zoology at Harvard College: Vol. XVIII. Cambridge, USA, John Wilson and Son, 215p.

Froese, R. 2006. Cube law, condition factor and weight-length relationships: history, meta-analysis and recommendations. Journal of Applied Ichthyology, 22: 241-253.

Froese, R.; Thorson, J.T. and Reyes, R.B. 2014. A Bayesian approach for estimating length-weight relationships in fishes. Journal of Applied Ichthyology, 30: 78-85.

Garth, J.S. 1946. Distribution studies of Galapagos Brachyura. Allan Hancock Pacific Expeditions, 5: 603-648.

Gerhart, S.D. and Bert, T.M. 2008. Life-history aspects of stone crabs (Genus Menippe): Size at maturity, growth, and age. Journal of Crustacean Biology, 28: 252-261.

Haddon, M. 2011. Modelling and quantitative methods in fisheries. Taylor and Francis Group, 433p.

Hall, N.G.; Smith, K.D.; Lestang, S. and Potter, I.C. 2006. Does the largest chela of the males of three crab species undergo an allometric change that can be used to determine morphometric maturity? ICES Journal of Marine Science, 63: 140-150.

Hartnoll, R.G. 1974. Variation in growth pattern between some secondary sexual characters in crabs (Decapoda, Brachyura). Crustaceana, 27: 131-136.

Hartnoll, R.G. 1983. Strategies of crustacean growth. p. 121-131. In: J.K. Lowry (ed), Conference on the biology and evolution of crustacea. Sydney, Australia Museum.

Hartnoll, R.G. 2012. Relative growth: description and analysis. p. 365-401. In: J. Forest and J.C. Von Vaupel Klein (eds), The Crustacea, Treatise on Zoology — Anatomy, Taxonomy, Biology. Leiden-Boston, Brill.

Hendrickx, M.E. 1992. Distribution and zoogeographic affinities of decapod crustaceans of the Gulf of California, Mexico. p. 1-12. In: M.E. Hendrickx; R.C. Brusca and P. Unitt (eds), Proceedings of the San Diego Society of Natural History. San Diego, California, San Diego Natural History Museum.

Hendrickx, M.E. 1993. Crustáceos decápodos bentónicos del sur de Sinaloa, México. Anales del Instituto de Biologia, Universidad Nacional Autónoma de México. Série Zoología, 64: 1-16.

Hendrickx, M.E. 1995. Cangrejos. p. 565-636. In: W. Fischer; F. Krupp; W. Schneider; C. Sommer; K.E. Carpenter and V.H. Niem (eds), Guía FAO para la identificación de especes para los fines de la pesca. Pacifico Centro-Oriental. Volumen I. Plantas e invertebrados. Roma, FAO.

Hilborn, R. and Walters, C.J. 1992. Quantitative fisheries stock assessment. Boston, Springer, 570p.
Holthuis, L.B. 1954. Observaciones sobre los crustáceos decápodos de la república de El Salvador. Comunicaciones, 34: 159-166.

Hurvich, C. and Tsai, C.L. 1989. Regression and time series model selection in small samples. Biometrika, 76: 297-307.

Huxley, J.S. 1932. Problems of relative growth. London, England, Methuen and Co. Ltd., 276p.

Josileen, J. 2011. Morphometrics and length-weight relationship in the blue swimmer crab, Portunus pelagicus (Linnaeus, 1758) (Decapoda, Brachyura) from the Mandapam Coast, India. Crustaceana, 84: 1665-1681.

Kalate, A.; Keikhosravi, A.; Naderloo, R.; Hajjar, T. and Schubart, C.D. 2018. Morphometric characterization of the freshwater crab Potamon elbursi Pretzmann, 1962 in the Caspian Sea and Namak Lake hydrographic systems. Journal of Crustacean Biology, 38: 91-100.

King, M. 2007. Fisheries biology, assessment and management. $2^{\text {nd }}$ ed. Oxford, Blackwell , 382p.

Koga, T.; Yoshino, K. and Fukuda, Y. 2010. Temporal changes in the reproductive population structures and males' secondary sexual character of the hermit crab Diogenes nitidimanus. Ecological Research, 25: 1007-1017

Kulbicki, M.; Guillemot, N. and Amand, M. 2005. A general approach to length-weight relationships for New Caledonian lagoon fishes. Cybium, 29: 235-252.

Maccormack, T.J and DeMont, M.E. 2003. Regional differences in allometric growth in atlantic canadian lobster (Homarus americanus). Journal of Crustacean Biology, 23: 258-264.

Marochi, M.Z.; Costa, M.; Daldin Leite, R.; Da Cruz, I.D.C. and Masunari, S. 2018. To grow or to reproduce? Sexual dimorphism and ontogenetic allometry in two Sesarmidae species (Crustacea: Brachyura). Journal of the Marine Biological Association of the United Kingdom, 99: 473-486.

Maszczyk, P. and Brzeziński, T. 2018. Body size, maturation size, and growth rate of crustaceans. p. 37-65. In: M. Thiel and G.A. Wellborn (eds), The Natural History of the Crustacea. Vol. 5. Life Histories. Oxford, Oxford University Press.

Mayer, P. and Giesbrecht, W. 1883. Crustacea. p. 4-62. In: Zoologischer Jahresbericht für 1882. II. Abtheilun: Arthropoda. Liepzig, Germany, Wilhelm Engelmann.

McLay, C.L. 2015. Moulting and growth in Brachyura. p. 245-316. In: P. Castro; P.J.F. Davie; D. Guinot; F.R. Schram and J.C. von Vaupel Klein (eds), The Crustacea, Treatise on Zoology - Anatomy, Taxonomy, Biology. Leiden-Boston, Brill

McLay, C.L. and Van den Brink, A.M. 2009. Relative growth and size at sexual maturity in Halicarcinus cookii (Brachyura: Hymenosomatidae): why are some crabs precocious moulters? Journal of the Marine Biological Association of the United Kingdom, 89: 743-752.

Milne-Edwards, A. 1879. Études sur les xiphosures et les crustacés de la région mexicaine. In: Mission scientifique au Mexique et dans l'Amérique centrale, ouvrage publié par odre du Ministre del'Instruction publique. Recherches Zoologiques pour servir à l'histoire de la faune de l'Amérique centrale et du Mexique, publiées sous la direction de M. H. Milne Edwards, membre de l'Institut. Paris, Imprimerie nationale. Cinquième partie. Tome premier, 368p.

Overton, J.L. and Macintosh, D.J. 2002. Estimated size at sexual maturity for female mud crabs (Genus Scylla) from two 
sympatric species within Ban Don Bay, Thailand. Journal of Crustacean Biology, 22: 790-797.

Pinheiro, M.A.A. and Fiscarelli, A.G. 2009. Length-weight relationship and condition factor of the mangrove crab Ucides cordatus (Linnaeus, 1763). Brazilian Archives of Biology and Technology, 52: 397-406.

Prototapas, N.; Katsanevakis, S.; Thessalou-Legaki, M. and Verriopoulos, G. 2007. Relative growth of the semi-terrestrial crab Pachygrapsus marmoratus: An information-theory approach. Scientia Marina, 71: 383-394.

Rathbun, M.J. 1930. The cancroid crabs of America of the families Euryalidae, Portunidae, Atelecyclidae, Cancridae and Xanthidae. Bulletin of the United States National Museum, 152: 1-609.

Rodríguez-Domínguez, G.; Castillo-Vargasmachuca, S.G.; PérezGonzález, R. and Aragón-Noriega, E.A. 2018. Allometry in Callinectes bellicosus (Stimpson, 1859) (Decapoda: Brachyura: Portunidae): single-power model versus multimodel approach. Journal of Crustacean Biology, 38: 574-578.

Salgado-Ugarte, I.H. 2013. Métodos estadísticos exploratorios y confirmatorios para análisis de datos. Un enfoque biométrico. Mexico City, UNAM, 299p.

Sanvicente-Añorve, L.; Salgado-Ugarte, I.H. and Castillo-Rivera, M. 2003. The use of kernel density estimators to analyze length-frequency distributions of fish larvae. p. 419-430. In: H. Browman and A. Skiftesvik (eds), The Big Fish Bang. Proceedings of the 26th Annual Larval Fish Conference. Bergen, Institute of the Marine Research.

Schwarz, G. 1978. Estimating the dimension of a model. The Annals of Statistics, 6: 461-464.

Silva, I.C. and Paula, J. 2008. Is there a better chela to use for geometric morphometric differentiation in brachyuran crabs? A case study using Pachygrapsus marmoratus and Carcinus maenas. Journal of the Marine Biological Association of the United Kingdom, 88: 941-953.
Silva, T.R.; Rocha, S.S. and Neto, E.M.C. 2014. Relative growth, sexual dimorphism and morphometric maturity of Trichodactylus fluviatilis (Decapoda: Brachyura: Trichodactylidae) from Santa Terezinha, Bahia, Brazil. Zoologia, 31: 20-27.

Somerton, D.A. 1980. A computer technique for estimating the size of sexual maturity in crabs. Canadian Journal of Fisheries and Aquatic Sciences, 37: 1488-1494.

Subramoniam, T. 2017. Mating Behavior. p. 131-158. In: Sexual Biology and Reproduction in Crustaceans. London, Academic Press.

Sukumaran, K.K. and Neelakantan, B. 2010. Relative growth and sexual maturity in the marine crabs, Portunus (Portunus) sanguinolentus (Herbst) and Portunus (Portunus) pelagicus (Linnaeus) along the southwest coast of India. Indian Journal of Fisheries, 43: 215-223.

Toro-Ibacache, M.V.; Manriquez-Soto, G. and Suazo-Galdames, I. 2010. Morfometría geométrica y el estudio de las formas biológicas: De la morfología descriptiva a la morfología cuantitativa. International Journal of Morphology, 28: 977-990.

Vélez-Cedeño, M. 2017. Caracterización de la pesca artesanal de la pangora (Menippefrontalis) en Posorja, Provincia del GuayasEcuador (junio-agosto 2015). Santa Elena, Universidad Estatal Peninsula de Santa Elena, 29p.

Widigdo, B.; Rukisah, R.; Laga, A.; Hakim, A.A. and Wardiatno, Y. 2017. Carapace length-weight and width-weight relationships of Scylla serrata in Bulungan District, North Kalimantan, Indonesia. Biodiversitas, 18: 1316-1323.

Zambrano, R. and Ramos, J. 2019. Morphometric variables of Menippe frontalis collected in Posorja, Ecuador. Mendeley Data, V1.

Zhang, Z.; Yokota, M. and Strüssmann, C.A. 2017. Relative growth pattern and relative condition factor in the Japanese mitten crab Eriocheir japonica (De Haan, 1835) (Brachyura: Varunidae). Journal of Crustacean Biology, 37: 571-578. 